\title{
Face Threats in Threads: Assessing the Responses to Impoliteness in Facebook Comments on 1MDB
}

\author{
ISMA NOORNISA ISMAIL \\ ${ }^{I}$ Faculty of Languages and Linguistics \\ University of Malaya \\ $\&$ \\ ${ }^{2}$ Academy of Language Studies, \\ Universiti Teknologi MARA, Cawangan Pulau Pinang, \\ Kampus Permatang Pauh \\ isma84@siswa.um.edu.my
}

THILAGAVATHI SHANMUGANATHAN

Faculty of Languages and Linguistics

University of Malaya

\begin{abstract}
Impoliteness has become common among online users and appears to be consented by netizens. This study seeks to investigate the reaction to impoliteness from the perspective of face-threat witnesses (FTWs) in Facebook comments. Twelve news posts on Facebook regarding the $1 M D B$ scandal in 2015 were selected, and impolite comment threads that were reactions to the news were extracted. Fifty-two threads were found to contain impolite comments targeted at non-participants of this interaction, thus corresponding to the characteristics of face-threat witnesses. Dobs and Blitvich's (2013) model for participant response options, Culpeper's (2011, 2016) Conventionalised Impoliteness Formulae (CIF) and Bousfield's (2007) list of defensive counter-strategies were used to analyse the responses. Impolite responses by the FTWs were found to be atypical. Denying the opposition either via being offensive or defensive subjugated the preference in the findings, though offensive appeared more prominently. Apart from deny opposition, corroborate opposition, and react, the current study also discovered new categories for the response options which did not fit in any of the categories, hence labelled as Distinct Features. The FTWs not only sanctioned impoliteness, but initial impoliteness in their responses, despite being 'other-directed'.
\end{abstract}

Keywords: Impoliteness; Face-threat witness; Responses; Facebook; Online Comments

\section{INTRODUCTION}

The internet has radically changed language use, and the subjugation of impoliteness on social media appears to be a common phenomenon (Crystal, 2006). Opinions and critiques are liberally posted on social media in a predominantly uncivil tone, especially when targeting public figures. And while this is a relatively new phenomenon in Malaysia, given the fact that defamation can land one in trouble with the law the 1MDB (1 Malaysia Development Berhad) case is a financial scandal which garnered both national and international attention, and became a popular topic of discussion among netizens. 1MDB was a strategic development company initially set up in 2009 to manage and expand investments in various sectors (Case 2017; Nazmi \& Rahim 2016). However, by 2015, allegations of its mismanagement became prime news due to its piling debt amounting to US\$11.6 billion (Wright 2015).

Print and social media were abuzz with reports of the case, but it was the Sarawak Report which began exposing the company's transgression with the caption 'The Heist of the Century' (Brown 2018). More allegations from the Wall Street Journal and the Sarawak Report implicated 
the then Prime Minister, henceforth PM, of various charges of misappropriating state funds (Nazmi \& Rahim 2016). All the allegations inflicted upon 1MDB as well as PM somehow contributed to the catastrophic downfall of the 61-year old hegemonic regime of the ruling party, Barisan Nasional in the $14^{\text {th }}$ General Election (Jaipragas 2018). Due to the huge publicity of the scandal, news on 1MDB triggered strong sentiments among citizens, and people took to social media to air their views and comments, hence justifying the selection of 1MDB as the focus of the current study.

Social media is the preferred mode of communication among netizens where of opinions were posted without much inhibition. The primary reason for this is the anonymity of online communication (Barbulet 2013; Herring 2001). This aspect of online communication has permitted netizens to post comments aggressively online, and these are often laden with emotional and uncivil remarks (Anderson 2012; Neurauter-Kessels 2011; Santana 2014). A considerable amount of literature has been published on the issue of politics and impoliteness in social media. Upadhyay (2010), for example, examined identity and impoliteness in reader responses to online news media through the application of the social psychological theory of identity. This analysis on the responses to news about the US presidential election in 2008 revealed that impoliteness was unequivocally linked to the respondents' self-identification with certain groups or ideologies.

Santana (2014) compared the level of civility in both newspaper and websites that either allowed anonymity or do not; and established that the comments in the latter were more civil than the anonymous ones. Similar findings were obtained by Rowe (2014), where a comparison of online political discussion was analysed in two different contexts, the newspaper's own website and its Facebook page. When a comment is posted, there is some form of identification that affects the manner of discussion while anonymity allows to some extent, the construct of impolite comments. A person's image is projected through the use of language in an interaction (Yaqin \& Shanmuganathan 2018). Since Facebook does not fully endorse anonymity, the users maintain their reputation online by filtering the content of their posts (Russett \& Waldron 2017). However, to what extent does self-regulation intensify impoliteness among Facebook users? Wang and Silva (2018) noted that Facebook participants displayed negative emotions after viewing uncivil political discussions and expressed high interest in wanting to engage in discussions of such nature as compared to civil discussions.

Impoliteness is bourgeoning, especially in the discussion of contentious topics on social media (Bennet 2013; Lorenzo-Dus, Blitvich \& Bou-Franch 2011; Rowe 2014; Sifianou 2019). Massaro and Stryker (2012) and Rowe (2014) argued that in order for this supposition to be substantiated, more empirical research should be conducted, hence the motivation to explore impoliteness within this online context. While numerous studies focused on dyadic communications, this paper is significant in the sense that it divulges impoliteness in the polylogal discourse on 1MDB issues and highlights the responses to impoliteness in the social media.

\section{IMPOLITE COMMENTS AND RESPONSES}

The conduct of impoliteness was initially regarded as "pragmatic failure, that was not worthy of consideration" (Culpeper 2011), and as such received lukewarm attention as compared to politeness. It is only recently that the magnitude of impoliteness has been regarded as "socially 
indispensable" and "highly salient in public life" (Culpeper 2013, p. 2; Sinkeviciute 2015). It is also a phenomenon that can hardly slip by undetected in an interaction, unlike its counterpart, politeness (Kasper 1990).

Despite its flourishing reputation, scholars cannot seem to agree on its definition. Watts (2003, p. 9) aptly describes, Impoliteness (is) a term that is struggled over in the present, has been struggled over in the past and will, in all probability continue to be struggled over in the future. Goffman (1967) defined impoliteness as aggressive face work, while Watts (2005) observed that it was problematic to evaluate whether certain interactional behaviours are impolite, polite, or appropriate as everyone has different perceptions when making these evaluations during an interaction. Of all the assortment of definitions on impoliteness proposed by various scholars, this study adopts Culpeper's (2011) notion of impoliteness;

\footnotetext{
"a negative attitude towards specific behaviours occurring in specific contexts. It is sustained by expectations, desires and/or beliefs about social organisation, including, in particular, how one person's or a group's identities are mediated by others in interaction. Situated behaviours are viewed negatively-considered "impolite"- when they conflict with how one expects them to be, how one wants them to be and/or how one thinks they ought to be. Such behaviours always have or are presumed to have emotional consequences for at least one participant; that is, they cause or are presumed to cause offence".

(Culpeper 2011, p. 23)
}

It is obvious that impoliteness is co-constructed and mediated in interactions which invite intense responses to either concur or refute the ongoing exchanges, thus appearing to sanction impoliteness (also Gilbert 1989). Dobs and Blitvich (2013) were particularly interested in facethreat witnesses' (FTW) response options, which facilitates the understanding of the coconstruction of impoliteness meanings and interpretations. Their study highlighted the dynamic and complex roles played by the FTW in small group discussion practices and proposed of the existing models of response options (Culpeper et al. 2003; Bousfield 2007, 2008) to incorporate FTWs' response options as highlighted in the current study.

\section{FRAMEWORK OF STUDY}

The data analysed in this study are online comments to the news regarding 1MDB posted on a newspaper Facebook page. These news posts from Facebook, defined as "internet-based form of interactive audience participation" (Neurauter-Kessels 2011), enables the users to share their opinion, discuss, and debate about the content of the news publicly. These interactions inherently involve more than two participants due to their unrestricted accessibility. Hence, Dobs and Blitvich's model was chosen for the current study as it takes into account multiple participant responses. This model is an extension to the earlier model by Bousfield (2007), which was more suitable for dyadic interactions. The proposed model for participant response options is displayed in Figure 1. 


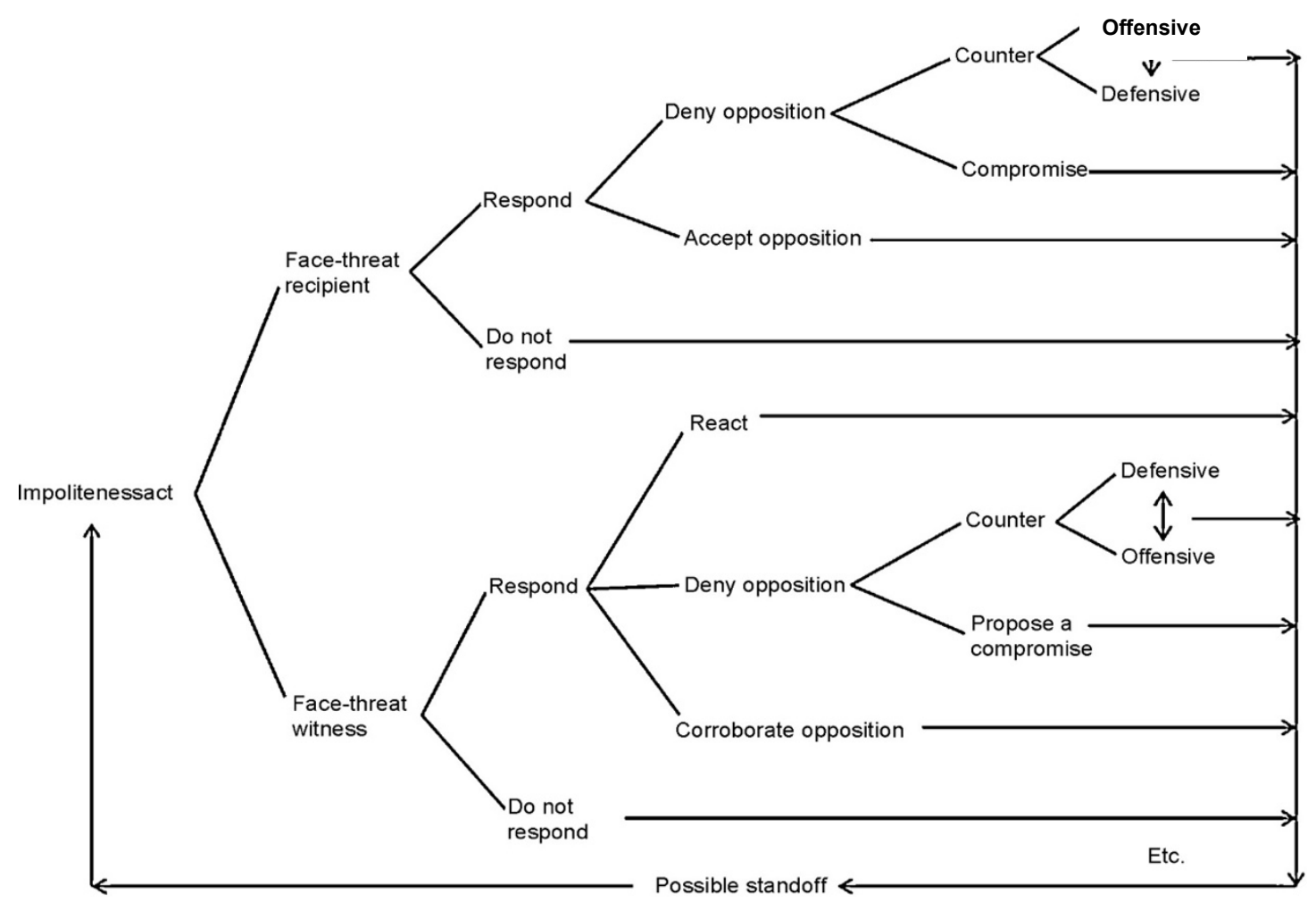

FIGURE 1. Model for Participant Response Options (Dobs \& Blitvich, 2013)

In this model, both face-threat recipients (FTR) and face-threat witnesses (FTW) have equal opportunity to respond to the impoliteness act by the face-threat initiator (FTI). In other words, the target of impoliteness is the FTR, while the FTW may be any active participant within the interaction, ratified or unratified, who witnesses the initial face-threatening acts. This study investigates the acts of FTW upon witnessing impoliteness, hence only part of the framework is adopted and employed, as displayed in Figure 2.

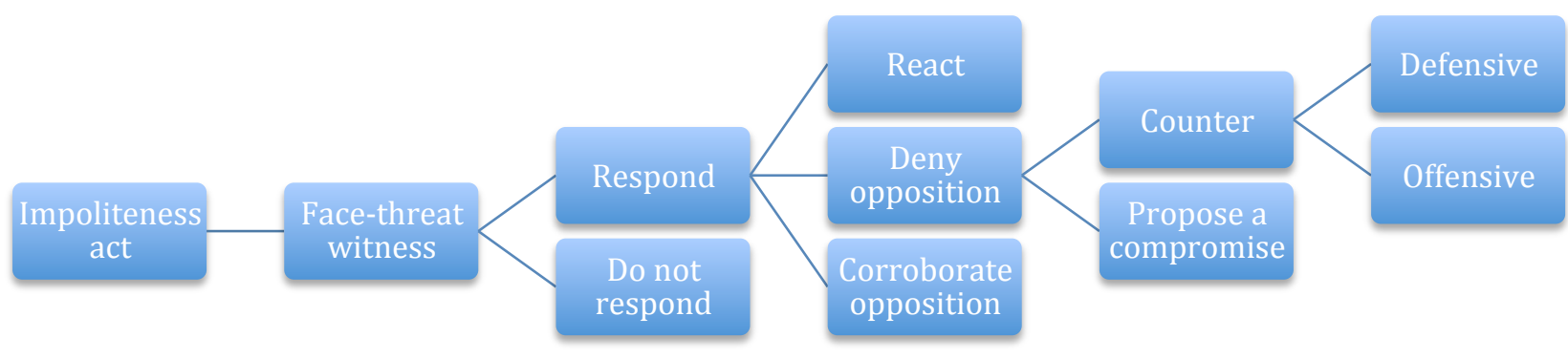

FIGURE 2. Response Options for Face-Threat Witness

Figure 2 shows several choices available to the FTW, i.e., whether to respond or not, and how to respond when a reactive comment is posted, deny opposition by compromising or countering, or corroborate opposition. The option to react is characterised by the impartiality of the FTW for not taking sides and only react to either heighten the drama or react with genuine surprise at the impoliteness issued (Dobs \& Blitvich 2013). If the choice is to counter, then the FTW can employ defensive or offensive strategies and Bousfield's list of defensive counter- 
strategies as well as Culpeper's $(2011,2015)$ Conventionalised Impoliteness Formulae to analyse these options. Corroborate opposition in contrast, is the act of accepting the face attack by assuming responsibility for the impoliteness or agree with the impolite assessment (Dobs \& Blitvich 2013).

Bousfield (2007) listed the summary of defensive counter-strategies that functions to "defend one's own face, or to champion that of a third party". This list is used to analyse the types of defensive strategies employed in the data for the current study and its abridged version is displayed in Table 1.

TABLE 1. Defensive Counter-Strategies (Bousfield 2007)

\begin{tabular}{|c|c|}
\hline Defence Strategy & Definition/Explanation \\
\hline Direct contradiction a.k.a. inversion & $\begin{array}{l}\text { This strategy works by simply denying the content of the } \\
\text { linguistic face-threatening acts issued by an interlocutor. }\end{array}$ \\
\hline $\begin{array}{l}\text { Abrogation (social and/or discoursal role- } \\
\text { switching) }\end{array}$ & $\begin{array}{l}\text { A counter strategy used to Deny personal responsibility for } \\
\text { the offence This can be done by switching social and } \\
\text { discourse roles. The switch from being the private citizen, or } \\
\text { the one being addressed; to the role of a public servant is the } \\
\text { example of social role switch whereas discourse roles switch } \\
\text { involve the interactants being the representative or the } \\
\text { spokesperson instead of the author. }\end{array}$ \\
\hline Dismiss: make light of face damage, joke & $\begin{array}{l}\text { Treating the face attack as something trivial is attributed to } \\
\text { this defensive counter strategy. }\end{array}$ \\
\hline $\begin{array}{l}\text { Ignore the face attack (whether explicit or } \\
\text { implied), offer insincere agreement }\end{array}$ & $\begin{array}{l}\text { This strategy of ignoring the face attack is evident in sarcasm, } \\
\text { whereby only the surface meaning is acknowledged. An } \\
\text { alternative within this strategy is by offering insincere } \\
\text { agreement to reduce the hostility following the impoliteness } \\
\text { event. }\end{array}$ \\
\hline Offer an account/ explanation & $\begin{array}{l}\text { Offering an account or explaining the action refers to the } \\
\text { attempt to present facts regarding the triggers that initially } \\
\text { caused an interlocutor to be impolite. }\end{array}$ \\
\hline Plead & $\begin{array}{l}\text { Pleading involves the scheming use of politeness strategies } \\
\text { which could possibly tarnish the image of the offender if the } \\
\text { face-attack is not withdrawn. However, the occurrences of } \\
\text { pleading in Bousfield's data sets were not identifiable; hence, } \\
\text { it is a theoretical defensive option. }\end{array}$ \\
\hline Opt out on record & $\begin{array}{l}\text { This strategy operates as the participant goes on record to opt } \\
\text { out of the conversation as a counter strategy. }\end{array}$ \\
\hline $\begin{array}{l}\text { Treat the situation as a different 'activity } \\
\text { type.' }\end{array}$ & $\begin{array}{l}\text { Shifting the face-threatening act from its original context to } \\
\text { another 'activity type' where the lexemes and structures used } \\
\text { are not taken as impolite. }\end{array}$ \\
\hline
\end{tabular}

Meanwhile, FTWs responses with offensive elements were examined with Culpeper's (2011, 2015) Conventionalised Impoliteness Formulae; as listed in Table 2.

TABLE 2. Conventionalised Impoliteness Formulae

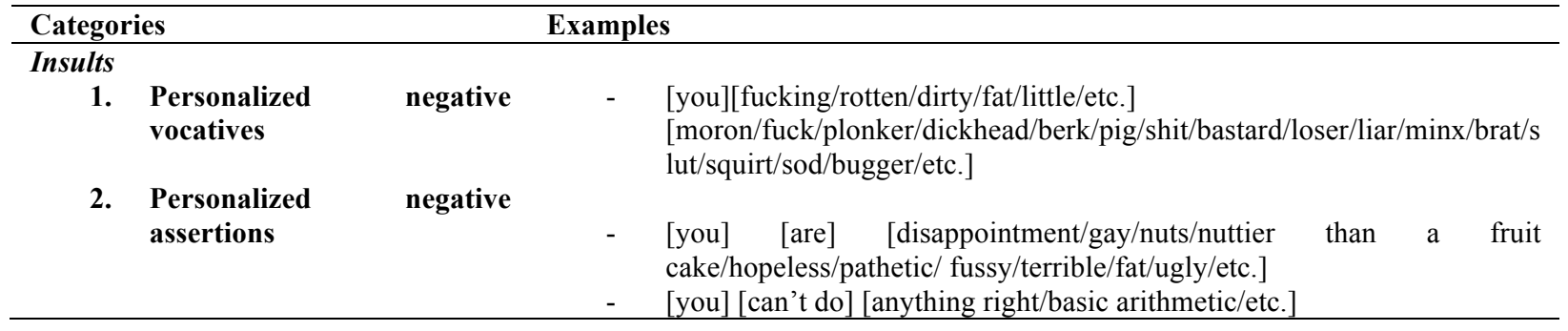




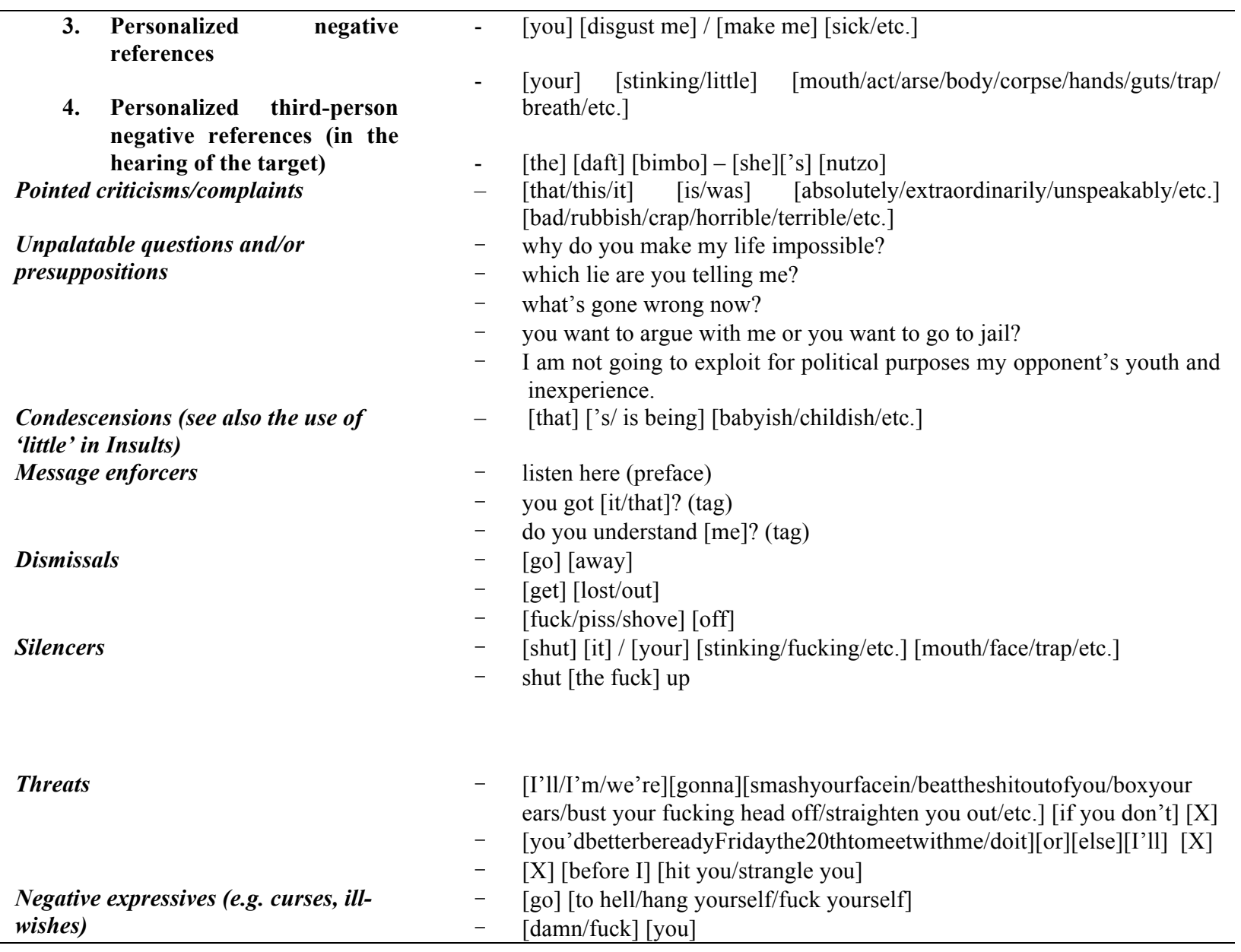

\section{DATA AND ANALYSIS}

Malaysia received international attention when news of the $1 \mathrm{MDB}$ was brought to light. Corrupt dealings involving $1 \mathrm{MDB}$ were reported, among which were overpaid commissions to a multinational investment bank and two corporations for the sale of its power plants, as well as donations transferred to PM-linked charities. In a gripping display of authority, PM ousted his deputy and a few other ministers who criticised him on this issue. MM who was PM's predecessor, withdrew his support and demanded PM's resignation, declaring that he was 'ruining the country' (Case, 2017). PM however managed to maintain his post until his imminent fall from grace at the $14^{\text {th }}$ General Election.

Following the substantial sequence of events happening in the year 2015, 12 news posts on the issue of $1 \mathrm{MDB}$ from January to December 2015 were extracted and the comments to the news were examined. Due to the profundity of this issue, people are still commenting on this, as one of the features of computer-mediated communication is longevity, once anything is posted online, it will be available for good (Graham \& Hardaker 2017). Despite the limitation in sample size, the news posts were able to capture the impoliteness phenomena in the online context (also Khan et al. 2019).

In order to analyse the responses by the FTWs, all the comments discussing the issue of $1 \mathrm{MDB}$ found on a newspaper Facebook page were extracted, and the target direction of the 
responses to comments with impolite qualities was determined to confirm their classification under FTW. The framework by Dobs and Blitvich (2013) was utilised to categorise the types of responses. Defensive responses to the initial impolite comment were analysed using Bousfield's list of defensive counter-strategies whereas the offensive comments were analysed using Culpeper's $(2011,2015)$ Conventionalised Impoliteness Formulae.

Findings indicated that $32 \%$ of the total 4176 comments were impolite and further analysis led to the discovery of 52 threads of responses to impoliteness. The rest of the comments were single posts, thus they were not included in the analysis as the focus was on threads of discussion. In all the 52 threads, the impoliteness directions were targeted at political and public figures, hence justifying the role of the commenters in the threads as FTW. This resonated with Rowe's (2014) findings that on Facebook, most incivilities were targeted at those who were not even participants of the discussion.

The identities of all commenters were coded according to their initials, although some commenters chose to use their real names in their profiles.

\section{FACE-THREAT WITNESS (FTW)}

When impolite comments are posted, readers may choose to respond to them. As such, readers who responded to comments that were aimed at those who were not present in the interaction (or 'other-directed'), are categorised as FTW due to their active role as witnesses to the coconstruction of impoliteness. From all the 52 threads, $54 \%$ of the impoliteness was directed at $\mathrm{PM}$ and the rest were directed at other politicians and public figures who were alliances of PM, e.g., S (15\%), P (9\%), K and G (8\%) and M (6\%). Facebook users who read the news posts, as well as the impolite comments, were considered as FTW and Table 1 lists the response options proposed as well as the frequency of occurrence (Dobs \& Blitvich 2013);

TABlE 3. The Participant's Response Options for Face-Threat Witnesses

\begin{tabular}{llll}
\hline Types & Specific response options \\
\hline (a) React (4) & Counter (76) & i) & Defensive (30) \\
(b) Deny Opposition (76) & Propose a compromise (0) & ii) & Offensive (46) \\
& & & \\
(c) Corroborate Opposition (32) & & \\
\hline
\end{tabular}

From the response options for FTW, it was found that the ratifying of impoliteness was apparent for options (b) Deny Opposition - Offensive and (c) Corroborate Opposition. Option (a) React, on the other hand, displayed impartiality as it did not reprimand nor ratify the face-threat whereas option (b) Deny Opposition - Defensive did not ratify impoliteness. The details of each response option with (a) React as the commencement are discussed below.

REACT

This response option has a distinctive feature of not countering the opposition and by taking sides with either face-threat recipients or face-threat initiator (Dobs \& Blitvich 2013). The reactions can be performed to either heighten the drama or react with genuine surprise to the impolite comment (Mueller, 2011). The example for this option can be seen in Example 1 from the news about PM's refusal to quit his post as PM. Despite mounting demands for his resignation, PM was unwilling to quit due to the belief that he still had his people's support. 


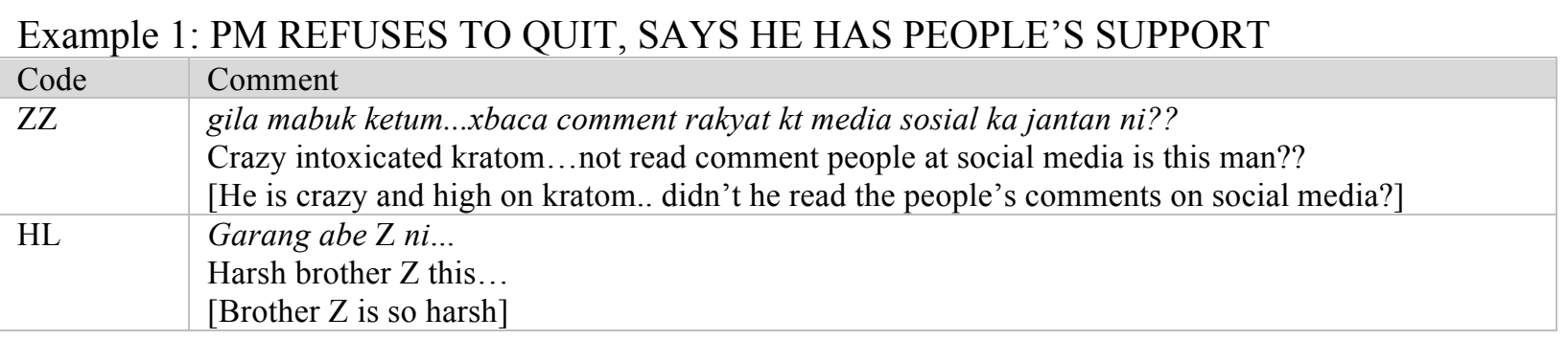

$\mathrm{ZZ}$ commented on the news by throwing insults at PM claiming that he was gila mabuk ketum which implied that he was crazy and intoxicated on ketum, (or kratom in English) - a type of opiate plant. ZZ continued to lash out at PM and accused him of not reading the comments posted on social media about him. PM was referred to as jantan in this comment, which is a reference to the male gender of animal and plants, i.e., the gender modifier is used to categorise $\mathrm{PM}$ as having attributes that were lower than an average man. In his response, HL reacted to ZZ as being garang (harsh or stern). This statement was classified as React since HL shared his opinion that ZZ was 'harsh' in his reference to the opiate and the gender modifier, without explicitly showing his support nor opposition to the insults issued by ZZ against PM. The display of neutrality in this reaction to the comment indicated that impoliteness was neither ratified nor opposed for this response option category, since the target of reaction was not the issue nor the person, but the commenter's use of language.

\section{DENY OPPOSITION / COUNTER / DEFENSIVE STRATEGIES FOR FTW}

A total of 30 comments from the FTWs were defensive in nature and these comments did not ratify impoliteness essentially because it was not addressed directly at the FTWs. Drawing from Bousfield's (2007) list of defensive counter strategies, only three out of the eight categories listed were significant in this study as the rest were only marginally discovered. The three are 'Offer an account/explanation' which can be referred to as the attempt to present facts regarding the triggers that initially caused an interlocutor to be impolite, whereas 'Direct Contradiction a.k.a inversion' works by simply denying the content of the linguistic face-threatening acts issued by an interlocutor. Another category, 'Dismiss', is an act of treating the face attack as something trivial. The analysis found that $57 \%$ of the comments used 'Offer an Account', while 'Direct Contradiction' came next with 32\%, and 'Dismiss' was the least (11\%) used.

A frequently used strategy by the FTWs was 'offer an account' as seen in Example 2 on AK's offer to help 1MDB repay its loan.

\begin{tabular}{l|l|}
$\begin{array}{l}\text { Example 2: } \\
\text { Code }\end{array}$ & $\begin{array}{l}\text { Comment } \\
\text { What a shame.. rakyat (citizen) helping govt instead the other way round.. now i wonder } \\
\text { whats he is going to get in return... }\end{array}$ \\
\hline GK & $\begin{array}{l}\text { He's not helping 1MDB to pay the loan, he's merely lending RM2bil to 1MDB so that he'll } \\
\text { get more in return when 1MDB's power unit goes IPO within this year. Pls read the article } \\
\text { before you guys whack the keypad. }\end{array}$ \\
\hline
\end{tabular}

$\mathrm{KN}$ slammed the government for having to rely on one of its citizens, $\mathrm{AK}$, to help repay 1MDB's loan. His contention that the government had lost its ability to repay its debt was obvious in 'what a shame'. He also appeared to think aloud and questions the motive of AK in 
wanting to help, procrastinating that it was in anticipation of some future return on investment. In response, another commenter, GK opined that AK was not helping to repay the loan as stated in the headlines or as thought by $\mathrm{KN}$, but was lending money to the government. By so doing, $\mathrm{KN}$ felt that $\mathrm{AK}$ would stand to gain more after $1 \mathrm{MDB}$ settled its listing of the power plant assets in the initial public offering (IPO). GK incited $\mathrm{KN}$ and other potential commenters to comprehend messages carefully prior to making hasty comments. The cynicism in GK's comment suggested the non-ratification of the condemnation to the government.

Likewise, the act of repudiating face-threat was another means of defensive strategy where Direct Contradiction was employed. Example 3 demonstrates PM's reluctance to resign despite the growing pressure on him to do so.

\begin{tabular}{l|l|}
\begin{tabular}{l} 
Example 3: PM REFUSES TO QUIT, SAYS HE HAS PEOPLE'S SUPPORT \\
\hline Code
\end{tabular} & Comment \\
\hline ARM & Nope. You DON'T have people's support. Please pack your bags. \\
\hline SC & 2 words can replace your sentences : f*** off hahahha $^{*}$. \\
\hline ARM & No, SC. I'm more cultured than that. -( \\
\hline
\end{tabular}

In Example 3, ARM snubbed PM's claims that he had the people's support and the reiteration of the word $D O N^{\prime} T$ (emphasised and in full capital letters) enforced the message that PM was no longer welcomed. He added a dismissal remark Please pack your bags at the end of his comment to insist that PM should resign from his post. SC replied to this comment and suggested an option that ARM's dismissive remark towards PM should be replaced with the provocative expression $f^{* * *}$ off. The usage of '*' to substitute the actual spelling for the phrase was an act of self-censorship, in order to reduce the face-threat impact (Jariah, Ng, \& Ainun, 2014).

At the beginning of the thread, ARM was the Face Threat Initiator, as he applied both Message Enforcer and Dismissal strategies to convey impoliteness to PM. SC who participated in the posting was the witness or FTW, who replied to ARM with an intensified face-threat, also directed to PM. Interestingly, ARM's role had shifted to being the FTW as he witnessed SC's face-threat issuance to PM that triggered his reply in the ensuing comment. SC's proposition of employing the highly offensive remark was snubbed by ARM. In fact, ARM mocked SC that he was more cultured than that. The emoticon suggested that while ARM did not condone SC's choice of words, he knew that SC was in agreement with him, hence a non-ratifying act.

\section{DENY OPPOSITION / COUNTER / OFFENSIVE STRATEGIES FOR FTW}

When responding to impolite comments, some commenters opted for offensive strategies, even when their face was not being attacked, and in this study, 46 responses were found to be offensive. Emotions were put on display as commenters channelled their anger towards the person or the issue in the news and resonated the same feelings as impolite responses were constructed using offensive strategies. Sarcasm was registered as the most regularly used impoliteness strategy, with a total of 55\% commenters opting for this strategy. This was followed by Insults (28\%), Dismissals (5\%), Pointed Criticisms and Negative Expressives, both at $4 \%$. Kleinke and Bös (2015) incorporated both first and second order approaches to impoliteness and found the prevalence of all the above strategies in their study although in a culturally different context, i.e., English and German online discussion. The pie chart in Figure 4 presents the percentage for the manifestation of impoliteness for each category. 


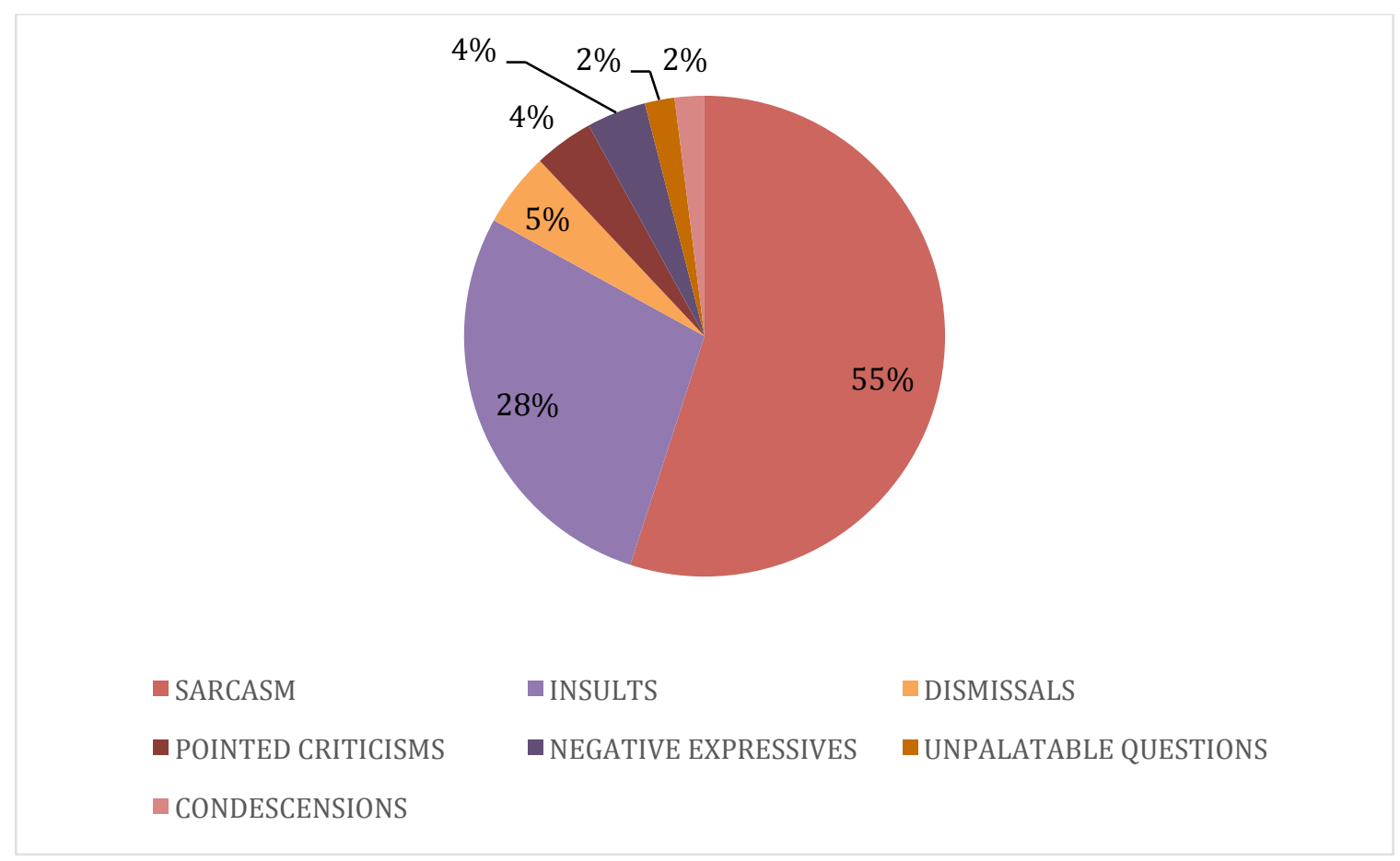

FIGURE 4. Percentage Of Offensive Strategies For Ftw

Sarcasm features the creative play of irony and ambivalence that conveys derision, and since it is featured as an implicature, thus appears indirectly impolite. The example of a reply employing this strategy was extracted from a thread in the news post about PM refuting the claim that he was involved with the Mongolian model who was assassinated.

\begin{tabular}{|c|c|}
\hline Code & Comment \\
\hline IZ & $\begin{array}{l}\text { True .. If } \mathrm{U} \text { are not involved .. Fine but who ordered the murder? People want to know } \\
\text { WHO? }\end{array}$ \\
\hline AA & $\begin{array}{l}\text { This is funny. He not even know altantuya then suddenly u ask pm who killed altantuya... } \\
\text { next time u also can ask PM where to find keys or anything else... stupid!!! }\end{array}$ \\
\hline
\end{tabular}

IZ reacted to the news by posting an Unpalatable Question to PM Fine but who ordered the murder? People want to know WHO? IZ demanded to know the identity of the mastermind behind the gruesome murder. This comment received mixed reactions from 14 other commenters, among which AA, who employed Sarcasm in her reply. Declaring that IZ's comment was amusing, AA flouted the Maxim of Relevance as IZ had not intended to be jocular. AA mocked PM's denial of knowing the female model, and IZ was just asking irrelevant questions to the wrong person. In this comment exchange, impoliteness was escalated further in the response through the usage of mockery and insult.

The use of offensive remarks with the intention to cause damage to the person receiving the face attack is the abridged demarcation of an insult. In Culpeper (2011), the Insult category is segregated into 4 different types, Personalized Negative Vocatives, Personalized Negative Assertions, Personalized Negative References, and Personalized Third-Person Negative References. The extract of choice is acquired from the news post on PM's allegation that attacks on $1 \mathrm{MDB}$ were all but lies. 


\begin{tabular}{|c|c|}
\hline Code & Comment \\
\hline RA (female) & $\begin{array}{l}1 \text { of his promise is No rise in tolls....but now to enter the city....we hv to pay at least Rm } 3 \\
\text { one way....whos the stupid minister that asked us to wake up early and use the no toll } \\
\text { route....bodoh punya kabinet... [stupid cabinet members] top to bottom full of stinky shits }\end{array}$ \\
\hline BL (male) & RA, looks like his Chicken's cabinet is full of idiotic brainless ministers. \\
\hline RA (female) & $\begin{array}{l}\text { BL the pea brains have been mixed up with their own bloody shits....make no difference } \\
\text { meh....... }\end{array}$ \\
\hline
\end{tabular}

RA criticised PM for not keeping his promise to maintain the toll price and chided one of the cabinet ministers for suggesting that everyone should wake up early and use the toll-free route in order to save on toll. Asserting that the minister was stupid, RA insulted the cabinet members by calling them top to bottom full of stinky shits. The response received for this offensive comment was an intensified insult to the cabinet ministers. BL replied to RA to express his ratification of the insult by adding his own version directed at the cabinet ministers. The ministers were labelled as idiotic and brainless and PM's choices of cabinet ministers were referred to as Chicken's cabinet. The ministers' analogy of chicken conveyed the insinuation of cowardice, the customary association with the fowl. RA also replied to BL and augmented the impoliteness in the comments by the ministers as pea brains to indicate their level of stupidity. RA also used Negative Expressive when claiming that they have been mixed up with their own bloody shits, and that all cabinet ministers were equally stupid, hence reinforcing their resemblance.

Both commenters opined that the politicians' comments were laden with insults directed at the cabinet ministers. It was a common civic awareness that being offensive was not condoned, yet none of them admonished the other, instead impoliteness was ratified as being offensive due to the fact that no damage was instigated since they were not at the receiving end of the insults.

Another category found in the replies to impoliteness was Unpalatable Question, as shown in Example 7 proclaiming PM's repudiation of his involvement with a Mongolian model, Altantuya (who was found murdered).

\begin{tabular}{|c|c|}
\hline Code & Comment \\
\hline CK (male) & $\begin{array}{l}\text { How is he not involved (as a Defense Minister then) when a c4 is used to blow up the } \\
\text { deceased? We are talking about c } 4 \text {. Not some mercun [fire crackers] of sort. }\end{array}$ \\
\hline WMR (male) & $\begin{array}{l}\text { so means terrorist sama IS pakai } \mathrm{c} 4 \text { bomb orang pun supply by jib ka? bodoh. [is the } \mathrm{c} 4 \\
\text { bomb used by IS and the terrorist supplied by jib (PM)? Stupid] }\end{array}$ \\
\hline
\end{tabular}

CK posted an Unpalatable Question doubting PM's denial of any links as he was the Defence Minister at the said time. The alleged murder weapon, the C-4 explosives can only be obtained from the Ministry of Defence, thus arousing the suspicion further. WMR replied CK's comment, cynically asking him if the C-4 bomb used by the IS and terrorists were also supplied by PM. He then labelled CK as bodoh or stupid in English. The responses were code mixed in English and the Malay Language, denoting casual spoken conventions. This comment functioned as a display of ire towards CK and the implied allegation, as well as to deliver a sliver of defence for PM. Impoliteness was not only ratified in this exchange, but further enhanced.

Pointed Criticisms or Complaints transpired when utterances or statements containing reproachful remarks were used to critic. This is evident in the news post about the help received 
to repay 1MDB's loan from the benevolent and affluent AK, one of Malaysia's richest men. The reactions to the news report were varied, some were happy and grateful, while others were doubtful, and some were even peeved at the act.

\begin{tabular}{|c|c|}
\hline Code & Comment \\
\hline KN (male) & $\begin{array}{l}\text { What a shame.. rakyat helping govt instead the other way round.. now i wonder whats he is } \\
\text { going to get inreturn... }\end{array}$ \\
\hline SBI (male) & $\begin{array}{l}\text { ini bodoh, ini bisnes, apa mo tlg2. } \\
\text { [this is stupid, this is business, what is help for? }\end{array}$ \\
\hline
\end{tabular}

$\mathrm{KN}$ in his comment discredited the government for having to accept help from a citizen when, in his opinion, it should be the contrary. He added a statement to show his suspicions on the benefits that will be reaped by $\mathrm{AK}$ as revenue from his favour. $\mathrm{KN}$ received six replies to his comment and among those was a comment portraying the features of Pointed Criticisms.

A commenter, SBI, replied in the Malay Language criticising KN's view that the government accepting favours as stupid. SBI went on to justify that this was a business deal and helping was usually not implicated in such deals. The criticism was mostly towards the content of KN's comment, and hardly concerning the impolite manner of how the comment was structured.

\section{CORROBORATE OPPOSITION}

Many commenters expressed their corroboration with comments containing impolite remarks as they were not directed at them. There was no damage or threat to their own faces, hence the unrestricted and bold agreement on the impolite comments issued. Example 9 shows unity in the responses to the netizen who commented on the news about PM's request that the issue of 1MDB not be made into a political football. The title of this news contains a metaphorical element associating politics with sports. This metaphor implied that politics was just how a game was played, where different people with different roles try to dribble the ball everywhere which resembled football. Hence, the phrase Don't make IMDB a political football suggested that everyone should stop playing around with this issue as it was not beneficial.

Example 9: PM: DON'T MAKE 1MDB A POLITICAL FOOTBALL
\begin{tabular}{|l|l|}
\hline Code & Comment \\
\hline KAH (female) & $\begin{array}{l}\text { You are not elected people...you are useless person now.....you misused power for } \\
\text { your own sake... Malaysian no need people like this...... need someone do for } \\
\text { people...not for you or your wife }\end{array}$ \\
\hline SAT (male) & Betul tu ! [that's right!] \\
\hline DSC (female) & Absolutely!! Muka tebal! [thick skin!] \\
\hline GL (male) & Totally agreed. \\
\hline
\end{tabular}

Instead of responding to the issue reported on the news, KAH criticised the PM to the point of insulting him. PM was labelled as a useless person and was accused of misusing the power for personal gain. The reference to PM was done only by the usage of the pronoun you which suggested the absence of respect for the Premier of Malaysia. The application of the pronoun you as well as the profusion of accusatory remarks in this comment also implied the reprimanding tone of $\mathrm{PM}$. 
A total of 3 commenters replied to KAH's thread and all three of them unanimously validated the insult and accusations thrown at PM. SAT instigated the reply in Malay, Betul tu which literally meant 'that is right'. There was no explanation why this commenter chose to demonstrate his full agreement with KAH's accusations and insults. The next comment was from DSC who exclaimed, Absolutely!! and supplemented with another offensive comment, Muka Tebal!! This Malay phrase signified a reference to a person who was 'thick skinned', or to indicate that someone was shameless. Both phrases were accompanied with double exclamation marks as a booster to intensify the volume of the shout. In written discourse, any words or phrases with exclamation mark is akin to verbal shout (Shea, 1994). The last comment in this thread was economical on its lexis count as it had only two words, totally agreed which showed a palpable corroboration to KAH's earlier offensive comment. All the replies ratified the accusations and insults hurled at PM despite no further justifications provided to support their agreement.

\section{DISTINCTIVE FEATURES}

New categories which we term as 'Distinctive' were found in the study, with a total of 34 comments falling into this category. This category did not feature defensive nor offensive categories, hence a new category that appears to be an extension to Bousfield's (2007) strategies and Culpeper's $(2011,2016)$ conventionalised impoliteness formulae is highlighted in this current study.

In this study, a total of 7 commenters were found to have incorporated suggestive remarks in their statements. It was marked when commenters replied to an impolite comment with suggestions or recommendations, by totally disregarding the impolite ramblings. An instance of such is given below.

\section{Example 11: PM SURVIVES POLITICAL RUMBLINGS}

\begin{tabular}{|l|l|}
\hline Code & Comment \\
\hline KTYJ (female) & $\begin{array}{l}\text { He's no survivor, he uses the police to intimidate everyone. Plus the fact that The Star } \\
\text { helps him by publishing only pro government news. Your anakanak Malaysia campaign } \\
\text { cannot cover the sins of your biased newspaper. }\end{array}$ \\
$\begin{array}{l}\text { This is why we all shall read and perceive from the authentic news, MalaysiaKini. } \\
\text { The Star help PM to cover up only. Aduh. [Alas] }\end{array}$
\end{tabular}

In Example 11, ML disapproved the news that declared PM was a survivor of political rumbling and in his comment, PM was portrayed as very manipulative for using the police to intimidate others. In addition, ML addressed the reference to an agency, the Star newspaper, and accused it of being biased by only publishing pro-government news. Citing another newspaper in contrast, KTYJ suggested that we all shall read and perceive from the authentic news, MalaysiaKini. This comment hinted that the Star reports were unreliable as compared to MalaysiaKini. KTYJ added in the last line the justification for her earlier statement, The Star help PM to cover up only. Aduh. This statement was apparently a baseless accusation due to the lack of supporting evidence. The use of agony remark at the end, Aduh signified the resentment towards the Star newspaper which explained why KTYJ suggested everyone to opt for a different newspaper as an alternate source of news.

In addition, another strategy used was warning, and it is issued to inform someone of a possible oncoming danger. This was done to ensure that the person was cautious and aware of 
his actions and its repercussions. Example 12 illustrates PM's refusal to quit and he even asserted that he had the support of his people. A Facebook user commented in this news post by combining a few impoliteness strategies such as sarcasm, insult, and message enforcer.

\begin{tabular}{l|l|l|l|l}
\hline Example 12: PM REFUSES TO QUIT, SAYS HE HAS PEOPLE'S SUPPORT \\
\hline Code & Comment \\
\hline AAV (male) & $\begin{array}{l}\text { Hahhaha....the joke of the day..only those who support GST is behind his back. Such a donkey } \\
\text { Mista Jibby. You didn't resign .We make you to resign!! THICK SKIN man }\end{array}$ \\
\hline DK (male) & $\begin{array}{l}\text { Careful, PDRM may come and find } \mathrm{u}: \mathrm{p} \\
\text { They are more into finding people whom comment like this in social medias instead of in } \\
\text { real :p }\end{array}$ \\
\hline
\end{tabular}

AAV initiated the comment with the written version of laughter and cynically added that the news is the joke of the day. He then asserted that only those who support GST is behind his back which suggests that not many people actually supported PM due to the backlash on the introduction of GST (Goods and Service Tax). AAV continued the comment with an added insult to PM by declaring him comparable to a donkey, an animal prominently known to signify folly and inanity. The insult was also intensified with AAV's reference to him as Mista Jibby instead of a more suitable and respectable designation. Mista is a non-standard spelling of the word Mister, spelled deliberately to reflect the speaker's pronunciation. Jibby was taken partially from PM's actual name and slightly altered to signify a masked term of endearment. AAV did not stop at that, instead he added the inclusive 'we', as a reference to himself and other Malaysians, will make PM resign. The last sentence in his comment was written in capitalized letters as a message enforcer to assert that PM was thick skinned.

In his response, DK warned him of the consequences of such words. He informed AAV to be wary as PDRM (Polis DiRaja Malaysia or the Royal Malaysia Police) were doing surveillance of people who wrote offensive comments on the social media and that action would be taken against them. By issuing such warning, it can be implied that DK acknowledged AAV's comment as impolite, however, the ratification or the reprimand was not obviously displayed which suggested that impoliteness was ratified and even encouraged.

Last but not least, some replies to impolite comments were in the form of challenge via query and these varied in the tones used. Questions were posed neutrally to seek clarifications, accusatory and aggravated tones were used. Example 13 shows a challenging question posted to netizens.

\section{Example 13: PM SURVIVES POLITICAL RUMBLINGS}

\begin{tabular}{|l|l|}
\hline Code & Comment \\
\hline ML (male) & $\begin{array}{l}\text { He's no survivor, he uses the police to intimidate everyone. Plus the fact that The Star } \\
\text { helps him by publishing only pro government news. Your anakanak Malaysia [children } \\
\text { of Malaysia] campaign cannot cover the sins of your biased newspaper. }\end{array}$ \\
\hline PS (male) & \begin{tabular}{l} 
What do you have to say, Star? Please comment. \\
\hline
\end{tabular}
\end{tabular}

This comment was from the news where the reporter applauded PM for surviving the political crises. One of the commenters, ML opposed the opinion of the reporter. He asserted that PM was no survivor and accused him of manipulating "the police to intimidate everyone." The focus of allegations in the last two lines then shifted from PM to the Star newspaper. The Star 
has been blamed for publishing only news that favoured the government, which justified the claim that it was biased.

PS replied to this comment by posing a question directly to the Star newspaper, What do you have to say, Star? Please comment. This comment had a challenging tone, requesting for clarifications and demanding the daily to defend itself from the allegations.

\section{DISCUSSION AND CONCLUSION}

The use of social media as the preferred choice of millions relying on this platform to communicate, and display online behaviours has a powerful effect (Barbulet 2013, p. 422) and impact on the netizens and agencies. Hence, this paper explored the reaction to impoliteness in the polylogal discourse of social media comments on the issue of 1MDB, a subject that has somehow elevated Malaysia to global fame. The responses by FTWs in this study validated the notion that besides ratifying impoliteness in this context (Neurauter-Kessels 2011), they also reinforced the responses with offensive strategies. Among the features of the responses from FTWs are: the different reference made to associate the targets of face-threat with animals, human body parts, incapacity in terms of physical or mental, and the dependency on others. In addition to that, the conspicuous display of code-switching by FTWs, enhanced the Malaysian flavour in the comments. The fact that the initial FTAs were not targeted at the face-threat witnesses emboldened their responses as their faces were not compromised.

The results also indicated FTW's preference ef in responding to impoliteness using offensive strategies as compared to defensive strategies. The analysis of offensive replies for FTW led to a significant finding whereby Sarcasm was the favourite strategy and this was followed by Insults. It was found that the FTWs in this study revelled in being offensive as a means to assassinate the character of PM via several methods such as addressing him with inappropriate identity markers, mocking his capability, and ridiculing his physique.

From the eight defensive strategies listed by Bousfield (2007), only three were prominent in the findings for FTW. In addition, the study also found replies that cannot be incorporated into either offensive or defensive strategies. These replies were amassed and categorised as 'distinctive'. This discovery demonstrated unprecedented ingenuity of the commenters, adding fervour to online communication.

The responses to impoliteness with somewhat equally impolite comments by the FTWs signified an important evaluation of the current online communicational behaviour among Malaysians. Despite not being inherent in face-to-face communications, impoliteness has now become ratified in the online realm, especially involving contentious topics like politics, and in this case $-1 \mathrm{MDB}$, a major scandal involving Malaysia's high ranking politicians. This phenomenon has also encompassed other types of social media for example, Twitter as the study by Marlyna Maros and Liyana Rosli (2017), which cited swear words and cursing as common.

Another possible reason for the rampant impoliteness is the fact that face-threat was directed at political figures, who, despite not being lawfully charged yet, were believed to be guilty of corruption by the public. Thus, the presumed conviction has liberated the FTWs from the guilt of their impolite expressions online. Overall it was observed that though some of the response options did not ratify impoliteness, other categories such as Deny Opposition (Offense), Corroborate Opposition as well as some categories in the newfound Distinct Features do ratify impoliteness with greater frequency as compared to the non-ratifying options. 


\section{L: The Southeast Asian Journal of English Language Studies - Vol 25(4): 34 - 50 \\ http://doi.org/10.17576/3L-2019-2504-03}

\section{REFERENCES}

Anderson, A. A. (2012). The Social Context of Online News: How Incivility in Online Comments Impacts Public Perceptions of and Public Engagement with Science. Unpublished PhD Dissertation, University of Wisconsin, Madison, USA.

Barbulet, G. (2013). Social Media-A pragmatic Approach: Contexts \& Implicatures. Procedia-Social and Behavioral Sciences, 83, 422-426.

Bennet, S. (2013, 11 April). Anti-Social Networks - 88\% Think People Are Less Polite When Using Social Media [INFOGRAPHIC]. Adweek. Retrieved from https://www.adweek.com/socialtimes/antisocialnetworks/481187/

Bousfield, D. (2007). Beginnings, middles and ends: A biopsy of the dynamics of impolite exchanges. Journal of Pragmatics, $39(2007), 2185$ - 2216. doi:10.1016/j.pragma.2006.11.005. Retrieved from http://ezproxy.um.edu.my:2095/science/article/pii/S0378216606002281

Brown, C. R. (2018). The Sarawak Report: The Inside Story of the IMDB Exposé. Selangor: Gerakbudaya Enterprise

Case, W. (2017). Stress testing leadership in Malaysia: the 1MDB scandal and Najib Tun Razak. The Pacific Review. Vol 30 (5), 633-654.

Crystal, D. (2006). Language and the Internet. Cambridge: Cambridge University Press.

Culpeper, J., Bousfield, D. \& Wichmann, A. (2003). Impoliteness Revisited: With Special Reference to Dynamic and Prosodic Aspects. Journal of Pragmatics, 35(10-11), 1545-1579.

Culpeper, J. (2011). Impoliteness: Using Language to Cause Offence. Cambridge: Cambridge University Press.

Culpeper, J. (2013). Impoliteness: Questions and answers. In Denis Jamet and Manuel Jobert (Eds.), Aspects of Impoliteness (pp. 2-15). Newcastle: Cambridge Scholars Publishing.

Culpeper, J. (2016). Impoliteness strategies. In A. Capone \& J. L. Mey (Eds.), Interdisciplinary studies in pragmatics, culture and society (pp. 421-445). (Perspectives in Pragmatics, Philosophy \& Psychology; Vol. 4). Springer

Dobs, A. M. \& Blitvich, P. G. C. (2013). Impoliteness in Polylogal Interaction: Accounting for Face-threat Witnesses' Responses. Journal of Pragmatics. 53, 112-130.

Gilbert, M. (1989). On social facts. Princeton, NJ: Princeton University Press.

Goffman, E. (1967). On face-work, interaction ritual: Essays on face-to-face behavior. New York: Pantheon.

Graham, S. L. \& Hardaker, C. (2017). (Im) politeness in digital communication. The Palgrave Handbook of Linguistic (Im) politeness. Palgrave Macmillan, London. 785-814.

Gunasegaram, P. \& Kinibiz. (2018). 1MDB The Scandal That Brought Down a Government. Gerak Budaya ENT, Selangor.

Herring, S.C. (2001). The handbook of discourse analysis. Oxford: Blackwell.

Ho, W.F. (2018). A brave new world for Malaysia. The Star Online. Retrieved May 13, 2018 from https://www.thestar.com.my/news/nation/2018/05/13/a-brave-new-world-for-malaysia/

Jaipragas, B. (2018). Ignoring 1MDB scandal caused UMNO's downfall in Malaysia: Najib Lieutenant Khairy Jamaludin. South China Morning Post. Retrieved June 6, 2018 from https://www.scmp.com/weekasia/politics/article/2149141/ignoring-1mdb-scandal-caused-umnos-downfall-malaysia-najib

Jariah Mohd Jan, Gillian Ng Mei Ing \& Ainun Rozana Mohd Zaid. (2014). Politeness and Self-Censorship in Chatroom Discourse Malaysian Journal of Languages and Linguistics. 3, 2014

Kasper, G. (1990). Linguistic Politeness: Current Research Issues. Journal of Pragmatics, 14, 193-218.

Khan, M. H., Adnan, H. M., Kaur, S., Khuhro, R. A., Asghar, R. \& Jabeen, S. (2019). Muslims' Representation in Donald Trump's Anti-Muslim-Islam Statement: A Critical Discourse Analysis. Religions, 10(2), 115.

Kleinke, S., \& Bös, B. (2015). Intergroup rudeness and the metapragmatics of its negotiation in online discussion fora. Pragmatics. Quarterly Publication of the International Pragmatics Association (IPrA), 25(1), 47-71.

Lorenzo-Dus, N., Blitvich, P.G. \& Bou-Franch, P. (2011). On-line polylogues and impoliteness: The case of postings sent in response to the Obama Reggaeton YouTube video. Journal of Pragmatics, 43, 2578-2593.

Marlyna Maros \& Liyana Rosli (2017). Politeness strategies in Twitter updates of female English language studies Malaysian undergraduates. 3L: Language, Linguistics, Literature ${ }^{\circledR}, 23(1)$.

Massaro, T. M. \& Stryker, R. (2012). Freedom of speech, liberal democracy, and emerging evidence on civility and effective democratic engagement. Ariz. L. Rev., 54, 375.

Mueller, A. (2011). Using a Genre Approach to Analyze Impoliteness in Classroom Discourse. Unpublished Master's thesis, University of North Carolina at Charlotte, North Carolina, USA.

Neurauter-Kessels, M. (2011). Im/polite reader responses on British online news sites. Journal of Politeness 
Research, 7(2), 187-214.

Papacharissi, Z. (2004). Democracy online: Civility, politeness, and the democratic potential of online political discussion groups. New Media \& Society, 6(2), 259-283.

Rowe, I. (2014). Civility 2.0; A comparative analysis of incivility in an online political discussion. Information, Communication and Society, 18(2), 121-138.

Russett, J. \& Waldron, L. (2017). It's Not Real Until It's on Facebook: A Qualitative Analysis of Social Media and Digital Communication among Emerging Adults in College. Social Sciences, 6(3), 74.

Santana, A. D. (2014). Virtuous or Vitriolic. Journalism Practice, 8(1), 18-33, DOI: $10.1080 / 17512786.2013 .813194$

Shahrul Nazmi \& Mohd Helmi Abd Rahim. (2016). The Reporting on the 1Malaysia Development Berhad (1MDB) Crisis and Implication on Efficacy of Economic and Financial News Reporting in Malaysia. Advances in Social Sciences Research Journal, 3(10), 12-21.

Shea, V. (1994). Netiquette. San Francisco: Albion Books.

Sifianou, M. (2019). Im/politeness and in/civility: A neglected relationship?. Journal of Pragmatics, 147, 49-64.

Sinkeviciute, V. (2015). "There's definitely gonna be some serious carnage in this house" or how to be genuinely impolite in Big Brother UK, Journal of Language Aggression and Conflict, 3(2), 317-348. Retrieved from http://www.jbe-platform.com/content/journals/10.1075/jlac.3.2.04sin

Upadhyay, S. R. (2010). Identity and impoliteness in computer-mediated reader responses. Journal of Politeness Research. 6, 105-127.

Wang, M. Y. \& Silva, D. E. (2018). A slap or a jab: An experiment on viewing uncivil political discussions on Facebook. Computers in Human Behavior, 81, 81, 73-83.

Watts, R. J. (2003). Politeness. Cambridge University Press.

Watts, R. J, (2005). Linguistic politeness research. In: Watts, RJ., Ide, S. \& Ehlich, K. (Eds.), Politeness in Language: Studies in Its History, Theory and Practice (2nd ed.) (pp. xi-xivii). Berlin/New York : Mouton de Gruyter.

Wright, C. (2015, 5 July). Can Najib Razak survive 1MDB scandal? Forbes. Retrieved from https://www.forbes.com/sites/chriswright/2015/07/05/can-najib-razak-survive-1mdbscandal/\#185bda76581f

Yaqin, L. N. \& Shanmuganathan, T. (2018). The Non-Observance of Grice's Maxims in Sasak. 3L: Language, Linguistics, Literature ${ }^{\circledR}, 24(2)$. 